\title{
Cognitive socialization: A model for cross-cultural education programmes
}

\author{
Margaret I. Meyer \\ Faculty of Education, University of the Witwatersrand, Johannesburg
}

In recent years many white-dominated organizations have attempted to encourage the development of black potential through special black advancement programmes. The concept of black advancement is contrasted with Africanization, the aim of which would be that blacks should plan and administer education programmes. Often black advancement programmes are based on a systems approach in which needs are identified, objectives set and regular tests administered. It is assumed that when objectives have been met, the participant is in a position to compete equally with his white counterpart. Often, however, subsequent performance has been disappointing, particularly to sponsors. In this article an approach of cognitive socialization is proposed which takes the student beyond the objectives set and encourages an outcome of quality. The research on which this article is based was undertaken at the University of the Witwatersrand with students in the Undergraduate Cadet Scheme who planned a career in commerce.

S. Afr. J. Bus. Mgmt. 17: $202-209$

Die afgelope jare het baie blankgedomineerde organisasies 'n poging aangewend om die ontwikkeling van swart potensiaal deur middel van spesiale programme ter bevordering van swartes aan te moedig. Die konsep van swart vooruitgang word gekontrasteer met afrikanisering waarvan die doel is dat opvoedkundige programme deur swartes beplan en geadministreer word. Bevorderings. programme vir swartes word dikwels op 'n sisteembenadering gebaseer waarin behoeftes geidentifiseer, doelwitte gestel en gereelde toetse gedoen word. Daar word aanvaar dat wanneer die doelwitte bereik is, die deelnemer in 'n posisie is om op 'n gelyke grondslag met sy blanke eweknie mee te ding. Die daaropvolgende prestasie is egter dikwels teleurstellend, veral vir die borge. In hierdie artikel word 'n benadering van kognitiewe sosialisasie voorgestel wat die student verder sal laat vorder as die doelwitte wat gestel word en 'n resultaat van gehalte aanmoedig. Die navorsing waarop hierdie artikel gebaseer is, is aan die Universiteit van die Witwatersrand onderneem met studente in die Voorgraadse Kadetskema wat beplan om 'n loopbaan in die Handel te volg.

S.-Afr. Tydskr. Bedryfsl. 1986, 17: 202-209

\section{Introduction}

In recent years South African organizations have put considerable energy and investment into black advancement programmes designed to fill educational and cultural gaps. The aim of the present article is to present a perspective from which to view such programmes if blacks are to realize their potential in preparing for a career in commerce. A common procedure in the past has been for educationists (usually white) to design black advancement programmes following a systems model in which certain objectives are to be met by the participants. In the present article the systems approach to education is critically examined and its limitations discussed. An alternative model of cognitive socialization is proposed which encourages contextualized understanding of the main issues, and is aimed at an outcome of quality and deep level understanding.

The research on which this article is based was undertaken at the University of the Witwatersrand (Wits) with a small group of black students who were selected by the AngloAmerican Corporation (AAC) to participate in a one-year post-matriculation pre-university programme, namely the Undergraduate Cadet Scheme (UCS). The aim of the programme was to equip the students to compete equally with whites. The present article is more specifically concerned with study skills and preparation for the Wits Commerce Faculty. The research covered a period of four years from the beginning of 1980 to the end of 1983, that is four successive intakes of students.

The research method was that of action research with the purpose of improving practice. Wherever possible data were collected by two or more methods so that it could be seen where the data supported or conflicted with each other. Not only were extensive records kept of interviews, observations of behaviour and verbal feedback from the black students and from university and company staff members, but experimental pre- and post-tests were administered for each intake. Subsequent results at university were studied and where possible causal connections traced.

The UCS was initiated jointly by Wits and the AAC, the participating students being known as cadets. A team of tutors and a full-time evaluator (all white) were appointed to devise and implement a course suited to the cadets.

A crucial distinction to be made at this point is between black advancement and Africanization. Stated simply, these two concepts are based on different views of cross-cultural problems. Such problems are usually explained according to either a deficit or difference model. The deficit model regards other cultures or minority groups as being handicapped by 
a deficit to be made up. The difference model views the two cultures as operating on different value systems, and finds it inappropriate that one culture should be assessed by the standards of the other (Edwards, 1979). In the case of the UCS, students from one culture were being prepared to function according to the expectations of another. The latter culture can be labelled modern technological society in which the language spoken is English.

The concept of black advancement calls for a programme to make up what is seen as a deficit. This is usually thought to be partly in achievement orientation, partly in language and cognitive skills, and partly in the organization of knowledge. White managers give examples of inadequacies which indicate an urgent need for black advancement programmes (see for example those quoted by Human \& Hofmeyr, 1985: 17). This need is manifested in the academic and vocational under-achievement of blacks when they find themselves in predominantly white institutions. Examples of deficits include poor English, lack of understanding of crucial issues, difficulty in verbalizing ideas, reluctance to ask questions, and a desire to please the questioner when answering questions (Human, 1984:113). Such examples lead to the commonly accepted white view that although blacks are handicapped at present, deficiencies can relatively easily be made up through programmes in language, communication and confidence building. Such programmes are based on a deficit model. In the case of the UCS, cadets had to learn to perform effectively in white-dominated institutions of modern technological society, namely, Wits and AAC or other sponsoring companies. One aspect of black advancement programmes which has often been neglected in the past but is very important is that of marginality (Human \& Hofmeyr, 1985:22). Blacks in white institutions often find themselves on the margin of the mainstream, receiving a vast number of conflicting and ambiguous messages. The present article refers to aspects of how the problem of marginality was addressed in the UCS.

The difference model with which the deficit model is contrasted can best be described by a brief examination of the perspective of Africanization. The latter might favour new educational structures and policies planned and administered by blacks to represent their more humanistic and communal world-view (Manganyi, 1981; Mphahlele, 1981a and 1981b) rather than the competitive approach of English-speaking technological society. Blacks might argue that their aim in the first instance should be to strengthen their own educational contribution. This might be done by encouraging self-reliance, confidence, a pride in black creativity and by institutionalizing cultural activities (Manganyi, 1981:35). For too long, it might be felt, blacks have seen themselves as 'subordinate members of society' and have experienced 'the muscle of white power as "total" in the ordinary circumstances of their lives' (Manganyi, 1981:36). They believe themselves to have been cut off from the heritage of their own people by white scholars (Manganyi, 1981:43), while power and identity in white institutions have eluded them, remaining as they do firmly in white hands. Moves towards black advancement are often seen as a belated attempt by the capitalist system to establish a black middle class. It has moreover not passed unnoticed by some blacks that even in the case of South African universities, power and identity remain white; that 'the particularly contentious or sensitive areas of the society are often only marginally examined where they are examined at all' (Welsh \& Savage, 1977:144). The example these authors give is: 'patterns of corporate ownership and control are all but avoided .... In psychology no deep study of the psychology of race and racism is offered by any South African university' (Welsh \& Savage, 1977:144, 145). Further it is noted that 'bourgeois psychology' is concerned mainly with 'such profit and loss issues' as black motivation (Manganyi, 1981:73). Representatives of the black community are, not unexpectedly, now calling for new structures and policies in education, planned and administered by blacks to reflect their world view rather than that of whites. Such planning should be based on a humanist philosophy, the tenets of which could be explicitly written into the curricula with a view to education for social change (Mphahlele, 1981a and b). Until such time as truly black-oriented universities can be established as opposed to the white-directed universities for blacks, blacks would see value in the established universities encouraging black participation. Manganyi (1981:166) looked forward to increasing numbers of blacks in administrative posts and full participation in governing councils. Structure and policies regarded as necessary include those which enable blacks to gain entry into business schools and professions such as engineering. The Council for Black Eduction and Research (Education Press, 1983) and the National Education Crisis Committee are at the time of writing (1986) attempting to clarify and elaborate on the educational needs of the community.

In the section which follows, the development of the UCS study skills programme according to a systems approach is described. This is to be seen as falling within the framework of black advancement, yet against the background of the known desire of many black educationists for Africanization programmes (Education Press, 1983). The literature on curriculum development and study skills is briefly referred to. This is followed by a description of how the systems model was implemented in the UCS, an assessment of its strengths and weaknesses and later substitution by a model of cognitive socialization.

\section{The systems approach}

The UCS team began materials development late in 1979 following a systems model (Rowntree, 1974), so that the programme would be ready by the time the cadets arrived in January 1980. Time did not allow for in-depth research of the strengths and weaknesses of different approaches. It was only later that this information was obtained.

The widely used systems model guides the learner towards predetermined learning outcomes (Stenhouse, 1975:4). Broad aims are set and then analysed into specific objectives (Stenhouse, 1975:54, 55). Test items are devised which can be used for pre- and post-tests (Rowntree, 1982:84-97). Content and teaching strategies are selected. After implementation the programme is evaluated using the aims and objectives as criteria.

The main criticism levelled against the systems model is that it mistakes the nature both of knowledge and of the process of improving practice (Stenhouse, 1975:79) because the ability to make relationships and judgements do not normally receive adequate focus. The value of the systems approach lies in giving clear direction to a team commencing work together, delimiting the content areas, allowing bonds to develop between team members as a result of working together, formulating common aims for a project and giving a framework for evaluation (Stenhouse, 1975:79).

In the case of the UCS, cadets were to be prepared not only for the Wits Commerce Faculty, but also for positions of at least middle management in AAC. In order to achieve the aim of equipping the cadets to compete equally with 


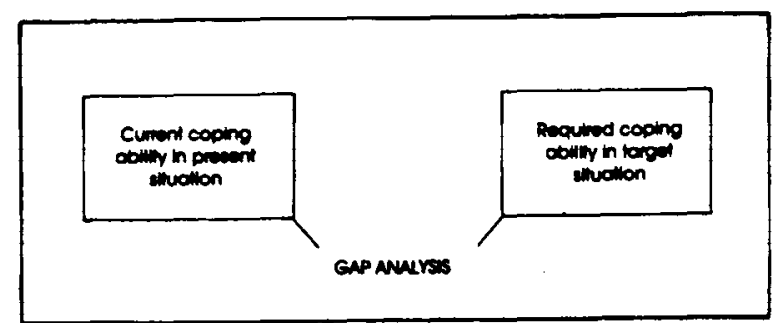

Figare 1 Model for needs assessment.

whites, the first task of the UCS team was to undertake a needs assessment which followed this model: (Meyer, 1985:62; Pinto, 1985).

Needs assessment was perforce undertaken before any cadets had been appointed to the programme, but it nevertheless aimed to analyse the gap between the present ability of black post-matriculants to cope with first-year university, and the required ability. Methods of obtaining information about needs consisted largely of interviews and informal discussions with a wide range of black and white university lecturers, students, persons in the sponsoring company and other companies, teachers and lecturers with experience in black education.

The format used in the case of university lecturers and those involved in the academic aspects was as follows: a range of skills was listed under appropriate headings, and those being interviewed were asked to rate the importance of each on a four-point scale. Space was provided for skills which had not been included. The weakness of this method is that data tend to be based mainly on the researcher's predetermined framework.

In the case of students, on the other hand, questions were asked relating to attitudes, personal anxieties, career opportunities, accommodation problems, other problems experienced on campus such as (for blacks) paternalism from whites, and a sense of isolation. Similar enquiries were made in industry.

In addition to the information collected through interviews and discussions, data were obtained during a training course for curriculum staff of the UCS. Speakers of distinction in black-white relations such as Professor L. Schlemmer of the Centre for Applied Social Sciences at the University of Natal and Professor N.C. Manganyi of the African Studies Institute at Wits, presented a variety of viewpoints as to the crucial issues. Further information for analysis was acquired through attendance at conferences and seminars, visits to other academic support programmes such as that at the University of Botswana, reference to published materials and the practical experience of teaching black matriculation students. The purpose was to establish a framework for the development of the components of the one-year pre-university course.

As the programme proceeded, there was continuing needs assessment, the outcomes of which were fed back into the system.

A problem which arises in connection with needs assessment is that of whose needs are to be met: those of the sponsor, those of the education institution or those of the student. This question was never explicitly answered in the UCS. Within a framework of black advancement, there would be far greater congruence of needs between sponsor and student than would be found within a framework of Africanization.

Following the systems approach, after the aims have been set and a needs analysis undertaken, the next step is a learning analysis. This includes first the analysis of goals and secondly the analysis of tasks. A task analysis identifies and isolates

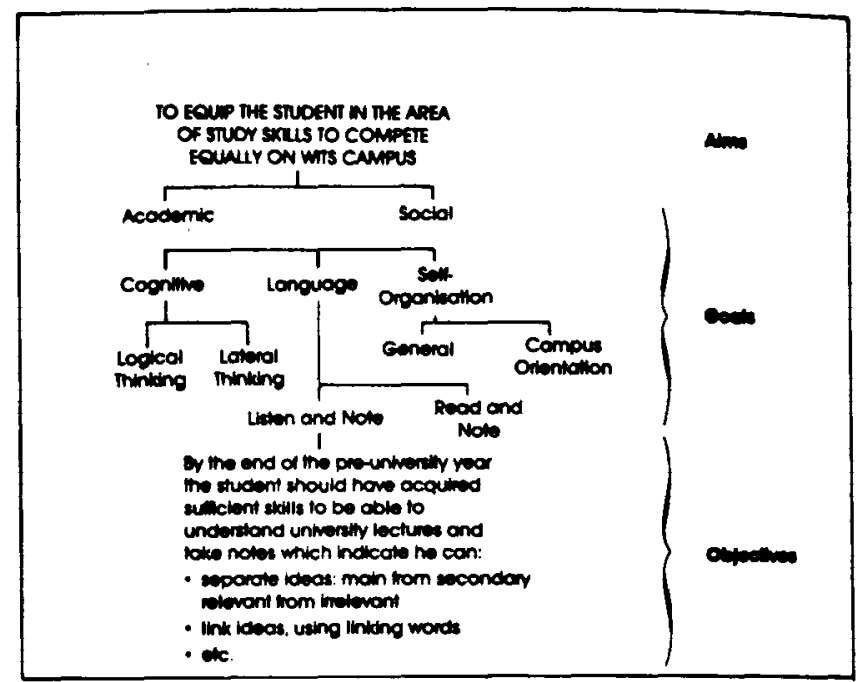

Flgure 2 Objectives derived from aims.

knowledge, skills and attitudes so that they can be synthesized in the design of the learning experience (Davies, 1971). Overt acts which characterize proficiency in the subject are arranged in a hierarchy and from these the objectives are drawn as shown in this example from the study skills programme of the UCS (Meyer, 1985:70).

Tests are then devised which may be administered pre- and post-training. In the UCS the design of the learning experiences included focus on such matters as sequencing, setting interim targets and selection of appropriate strategies. Classroom procedure involved formal lectures, programmed selfinstruction, tape recordings, group work, pair work, role play, simulations, discussions, peer teaching and practical exercises such as using the library, using the microfiche and going to see lecturers in their offices.

In working through the study skills component, the main problems experienced by cadets appeared to be in connection with language and related problems, organization of work, learning style, and campus orientation.

Language problems included deficient vocabulary and grammar which at times affected performance in other subjects, but less so than for example use of excessively colloquial English. The pronunciation of some of the cadets was a problem to their tutors, but there were such negative reactions to pronunciation classes that they were not pursued. This response might have been anticipated in view of the known attraction of adolescents to an external reference group whose accent symbolizes the values to which the young person aspires (Lanham, 1983). This problem is one of a sociolinguistic nature and again should remind the educator of the anomalous position in which students entering black advancement programmes find themselves. Many problems were loosely labelled 'language', though on investigation they proved to be conceptual problems or problems relating to the student's lack of experience of the total context. Similarly, problems at first diagnosed as failure in logic were often found to relate to what is usually termed 'general knowledge'. It should be noted here that the latter generally refers to knowledge which is shared by those reared in western industrial society in an English-speaking community. As the UCS programme proceeded it became apparent that the knowledge of the total context which a student brings to a task is as important as the instruction he receives in the task itself.

Much of the malaise facing the marginal man (see Human, 1984:114) appears to lie in the confusion arising from the 
different cognitive contributions he is able to make. Some elaboration is necessary here of what this knowledge is that is brought to a task. It can roughly be divided into three categories, namely language in social context, conceptual structures and knowledge of contexts. Language in social context includes knowledge of one's own social status, awareness of the conventions and routines which govern particular situations (Fillmore, 1973:13), what is supposed to be accomplished by various contributions, and attitudes and behaviour appropriate to each situation. This type of knowledge is usually assumed by whites accustomed to Englishspeaking modern technological society. Most blacks, however, were brought up in a different culture. In the case of cadets, usually aged about 19, they are attempting to acquire this knowledge at a time at which reference group behaviour and peer approval are of particular importance (cf. Criper \& Widdowson, 1975:176-177). The need to demonstrate group loyalty is compounded in the present South African situation where 'some students feel as if they are being left out of communally acceptable levels of heroism, what with frequent reminders of political trials, bomb blasts and commemoration services' (UCS Document quoted in Meyer, 1985:97). Language in social context also requires an understanding of the setting of interactions, the roles of participants, the relation between what is said and what is done, that is, how the linguistic form relates to the social meaning and action (Criper \& Widdowson, 1975:202). It should be noted that some writers on the problem of deficit (e.g. Edwards, 1979) have reached the conclusion that the difficulties of blacks in white institutions do not reside in themselves so much as in the attitudes of those around them. Any long-term solution must consequently be in both the eventual elimination of prejudicial attitudes and the addition of standard English to the speaker's repertoire so that there can be unimpeded communication (Edwards, 1979:26).

With regard to the development of conceptual structures, the acquisition of concepts is not simply a matter of memorizing words. However, this fact has not always been recognized by educators, thus a rote-learning phenomenon has arisen in black schools, not only in South Africa, but in other African countries as well. Hence it is hardly surprising to read that 'a large South African corporation found ... African employees had assimilated a body of facts without digesting or properly understanding the material ... difficulty was experienced in verbalising thoughts and ideas' (Human, 1984:113). Vygotsky (1962) has drawn attention to the fact that certain thoughts cannot be communicated until the necessary concepts have been acquired. It is well known that cultures differ in the availability of concepts (Brown, 1956). Those students from backgrounds other than modern technological society have consequently formed conceptual structures which differ from those generally assumed in whitedominated universities and businesses.

A third factor contributing to the knowledge brought to a task is an understanding of the context. Context is the setting in which events occur and which establish or help to establish their meaning. Events include verbal and non-verbal interactions, concepts and objects. Understanding involves perception of an object's role in events (Bransford \& McCarrell, 1975), and the role of one event in a chain of events. To give a very simple example, the newcomer might not appreciate the significance of placing a letter in the IN basket rather than the OUT basket. The observer or participant in such events (possibly, the reader, writer or messenger) is required to make cognitive contributions in order to create meaning and act upon it. The ability to make appropriate contributions depends on the comprehender's knowledge of both the context and of the event itself, and to do so he uses what he knows of the event and the context. The meanings which are created may not always be the same because of the different contributions from different comprehenders (Bransford \& McCarrell, 1975). A whole sentence, for example, may be understood differently because of a different interpretation of the larger context in which it is heard. The newcomer's past experience of events in context will have affected his cognitive functioning. The opportunity for a variety of experience as well as the amount of practice appear to be central to the application of cognitive skills, and input from the specific context appears to be necessary to activate particular concepts (Skemp, 1979:32). There is likely to be misunderstanding unless the newcomer is aware of events in a wider context and has some experience (actual or vicarious) of the topics he is expected to understand.

Considerable attention has been given to the question of the knowledge which a student brings to a task because it has proved to be of vital importance both at university and in industry. When the UCS started, curriculum developers were not aware of the importance of the students' peripheral knowledge, therefore the systems approach as used in the UCS addressed only the task itself. For example, consider the first objective of the listening and note-taking unit quoted above. Those students who were familiar with the context of a particular subject and had understood the lecture were well able to separate ideas, main from secondary, relevant from irrelevant (in some cases regardless of whether tuition was offered or not). Moreover, as regards language, it was noted that certain students were able to establish credibility despite language difficulties, either through the force of their personalities or through the way they were able to convey a message, errors notwithstanding.

As previously noted, the outcome of a systems model is predetermined. The focus is on what, at the outset, the planners believe to be the important issues. In the case of the UCS, performance of certain tasks such as good note-taking was only later seen to be the overt behavioural manifestation of internalized knowledge. Thus it was only as the programme developed that there emerged a need for the instructional aim to shift from that of taking acceptable notes (to use the listening and note-taking example again) to the aim that the students should understand the lecture and its context well enough to be able to take acceptable notes. Similarly in the case of logical and lateral thinking. A cadet recognized as a good lateral thinker in the pre-university year, was, in first year described by a lecturer as

'imaginative and provided sufficient discussion and analysis to pass the two marketing questions, although marginally failed to interpret the questions accurately and provided random uncoordinated thoughts, most of them irrelevant.'

It appeared that exposure to the context in which cadets would develop skills with the focus on points of difficulty would in all probability provide a better learning experience than instruction in skills out of context.

When a systems approach is used, the presentation of materials is generally followed by evaluation which usually assumes that difficulties are due largely to inadequacies in the materials or teaching, and that these should be modified to enable students to learn. A formative evaluation is often used in the process of developing and improving a course in order to facilitate the achievement of the objectives set. In the UCS 
as part of the evaluation, a validated test was administered to the cadets at the end of the pre-university year. The results of this test demonstrated that within the closed system of the pre-university year objectives had been met. However, when the first university examination results became known, it appeared that the way in which the systems approach had been used in the UCS had not provided the means to achieve the aims. The topics selected appeared to be not irrelevant in themselves and had the potential to form the basis of a reliable programme. It was, however, suspected that a superficial rote-learning style was being encouraged. As two cadets put it: 'Setting limited objectives is too constraining. There is no incentive to read more and there should be a much wider field' (Meyer, 1985:107). The aim of equipping cadets to compete equally with whites was only partially achieved. The relationship between aims and objectives had somewhat naively been assumed to be a direct one, but in practice had proved to be an extremely complex one in the present situation. A new perspective was required which would result in learning of greater quality, but which did not necessitate discarding the existing objectives. A broader framework was therefore sought which could include issues which could not be identified early in the programme, but might emerge as the programme progressed. Objectives arrived at through the analysis of aims and goals would continue to be part of the course content, but as the students' world-view expanded, they would form part of a deeper knowledge.

\section{Cognitive socialization}

The new framework which was developed has been called the model of cognitive socialization. It was developed in the UCS in an attempt to eliminate some of the shortcomings of the systems approach as described above. Before the model of cognitive socialization is presented, however, it is necessary to discuss briefly two approaches to curriculum development other than the systems approach, namely the process and research approaches. The three are not necessarily mutually exclusive.

In a process approach the learning outcome is open-ended (Stenhouse, 1975). The essential principles and features of a curriculum are presented in such a form that it is open to critical scrutiny and capable of effective translation into practice. The ideal process curriculum is designed not on a prespecification of behavioural objectives, but on the idea that knowledge must be speculative and thus indeterminate as to student outcomes if it is to be worthwhile. It aims to avoid the distortion of knowledge attributed to the translation of the deep structures of knowledge into behavioural objectives. The fact that knowledge can always be deepened is recognized. One of the acknowledged limitations of the process model lies in the fact that it can never be directed towards an examination as an objective without losing quality and cannot be used by rote learners because it depends on broader educational aims.

A research model aims to advance knowledge of the problems in a particular field (Stenhouse, 1975). In creating the curriculum, the developer also takes on the role of an investigator of the curriculum. She or he believes the curriculum evolves and improves as its shortcomings are studied and gradually eliminated. A curriculum without shortcomings would be viewed as having been insufficiently ambitious because it can offer no prospect of improvement. The curriculum is judged by whether it advances knowledge rather than by whether it is 'right'.

It was with the three approaches to curriculum development in mind, namely the systems approach, the process and research approaches, that the model of cognitive socialization was developed. A fresh perspective on the student and his learning in a new environment was taken which subsumed the skills and content previously identified through the systems approach.

The general aim was to devise a programme the outcome of which would be learning of quality. This implies a deep understanding of the significance of the issues. Quality learning has been defined as that in which knowledge is construed by learners as a result of active effort to abstract meaning and to relate this meaning to reality outside the immediate lecture or text (Dahlgren \& Marton, 1978; Gibbs, Morgan \& Taylor, 1982).

The new perspective required that certain facts be taken into account. For example, it is well known that a human being tends to be the kind of person his language, his traditions, and his tacit knowledge tell him he is and that he uses the common sense of his community to understand the world (Cohen \& Manion, 1980:191). When new social roles are to be fulfilled the necessary new skills and attitudes are acquired through a process of socialization (Mayer, 1970:xiii). Socialization is the way individuals become members of a society (Schwartz, 1976:ix). The processes of socialization are 'all those social experiences that one supposes "actually" advance people in their role-playing skills or attitudes (Mayer, 1970: xviii)'.

In the case of the UCS the socialization required was that the cadets should be able to achieve in the environment of a predominantly white university and the white-dominated world of large business concerns. Both these contexts are remote from the average cadet's own past experience, thus what was required was a number of social experiences which would advance the cadets in their roles as students at Wits and as potential managers in industry. It has been suggested that the forces of learning through imitation are much more powerful than the forces of learning through tuition (Mead, 1930). If this view is accepted then it can also be accepted that the general stream of the tradition, including language, manners and attitudes could be imparted effortlessly if students are placed in the context in which they are expected to operate (Mead, 1930). However, even when this is done persons entering a new situation inevitably bring in important influences from the previous context. For example, in order to understand a situation, the newcomer uses a code which he has learnt in a previous context. Coding systems enable people to make new and fruitful decisions. Knowledge of the code applicable to a particular situation enables the participant not only to interpret familiar aspects correctly but also to 'go beyond the given' (Bruner, 1974). However, reliance on a particular code acquired in one context may inhibit understanding of a new situation because aspects have been precategorized incorrectly.

Consideration of the code raises the question whether a course for blacks only, such as the UCS, fails to make full use of a most important and readily available resource, namely studying in a mixed group with whites. Programmes for both blacks and whites studying together have certain advantages for blacks. An example is in the training approach suggested by Piron, Human \& Rajah (1983:17). Further advantages for blacks are:

- Blacks learn new ways of behaviour from white peers;

- Blacks learn to understand and interpret modern technological society from their white peers who are more familiar with this society; 
- An opportunity is provided for bläcks to acquire relatively effortlessly the language and concepts used by their white peers.

Such a programme would be akin to a language programme which depended on simple exposure to the new language. Though much is learned at a survival level, refinements are often lacking. Many second language speakers who have lived in an English-speaking environment for decades show no improvement in the language after the first year. The reason is usually that the speaker remains unaware of the shortcomings in his speech. Similarly blacks often remain unaware of differences in their speech, attitudes and behaviour until these receive the focus of attention and are explicitly discussed. Whites are of course also unaware of many of the complexities of cross-cultural communication. However, because they form the mainstream dominant group at the present time, they may also form a threat in discussions of cultural differences. Human \& Hofmeyr (1985, chapter 7) and Pinto (1985) have dealt in some detail with self-esteem and attitudes towards western culture. Some of the advantages of a programme for blacks only are:

- Blacks have the opportunity to identify their own problems and attempt solutions without possible red herrings introduced by less gifted whites or whites who have failed to take full advantage of their opportunities, yet who may tend to dominate.

- Blacks have the opportunity to establish the ethos and gain confidence before they find themselves having to compete with whites.

- Blacks who have the potential but who have not had opportunities in the past receive the kind of programme best suited to helping them.

- Blacks are able to support each other until such time as they have gained sufficient confidence to feel less alienated in a white institution.

- Blacks have the opportunity to become aware of the different coding systems of modern technological society in an environment, which, because of the absence of whites, is less threatening to them.

In the event, the UCS attempted to reap the benefits of both types of programmes by having the cadets attend firstyear lectures with mixed groups of blacks and whites. These were followed by report-back sessions for cadets only at which they aired their problems.

An example of a different coding system with which black students enter commerce is to be seen in the views which applicants to the UCS expressed on Commerce. Most of the aspirant cadets emphasized thrift as the salient characteristic of the 'commercial man'. He was seen as one who budgets his money and saves, uses the bank, buys insurance policies and is prepared to lend money for interest. He was said by applicants to be ambitious, systematic, generally hardworking and cautious, sometimes to the point of meanness. He was considered to be well-informed, influential, and to enjoy a high status in the community as a result of his education. He was described as being dignified, wearing formal dress, getting on well with other people and planning ahead. The businessman was contrasted with those with no understanding of commerce such as the labourer. The 'non-commercial' person was generally seen as a spendthrift and often a drunkard who squandered his money. 'An accountant', remarked one applicant, 'can hardly buy three cans of beer to satisfy himself only, whilst a labourer can easily buy about thirty-six to satisfy the whole mob he has befriended (Meyer, 1985:140). There was no mention of the risk-taking entrepreneur, nor of a career in commerce, nor was any contrast drawn with persons in other professions. This general attitude towards commerce might be described as the code or group bias with which cadets entered the programme. In providing a programme for the cadets, it was important to fill not only the gaps in knowledge, but also to take into account the code or group bias.

The new context which students enter is to be seen in terms of both the explicit context and the implied context. The explicit context is the university and the industrial organization sponsoring the cadet. The university context is more particularly the Commerce Faculty, including the course content, methods and the students' interactions. The implied context is the white business world of South Africa and the West. Some basic understanding of these contexts is required by the student before he or she can make contributions which will result in a deeper level of understanding. An example of a contrast between a surface level and a deep level of understanding occurred when pre-university cadets were asked to study a few pages of an economic text in preparation for a test. In the test one student accurately reproduced a table of numbers consisting of two columns each six lines deep a total of twelve numbers, five of which ran into four or five figures. His comment on the table which concerned black and white agriculture was merely to restate what the figures already indicated, namely that production was higher in white agriculture. Another student, by contrast, had remembered far fewer figures, but in commenting was able to emphasize the factors which contributed to the lower output of blacks. For example, he noted that black men left the rural areas because what they could afford to grow was not sufficient to meet their needs and those of their families. In other words, the second cadet was able to explain the significance of the figures while the first student was able merely to reproduce them. The first cadet appeared to study at a superficial level while the second cadet appeared to have a deeper level of understanding. The latter was beginning to achieve the aim of quality learning. He construed knowledge for himself based on the facts presented in the text. He had himself made the effort to abstract a wider meaning from the figures and had related them to reality beyond that particular text. Through his knowledge of a wider context he had been able to bring to his study some background and contextual information so that he could make appropriate cognitive contributions to the task at hand. In the case of students who lack knowledge of the implied context, no amount of active effort enables them to derive more meaning than that provided by the initial reading or lecture, because for them, there may be no related outside reality, or there may be an outside reality which is different from that of modern technological society so that they are unable to make the logical connections.

In devising a programme of cognitive socialization for the cadets, it became essential to devise a spiral or cyclical curriculum leading to deeper levels of understanding.

Figure 3 represents the student progressing towards deep level understanding in a pathway affected by previous and present contexts both explicit and implicit. The student enters an intervention programme with his own bias and code derived from the experiences of his previous environment at home, at school, and in his community. There a language other than English is spoken while ways of thinking, that is cognitive activities, differ from those of the new environment. He tends to bring to the new situation experiences, ideas, and ways of thinking, in other words a whole range of cognitive contributions, which may have been appropriate in his previous environment, but which are often discontinuous with 


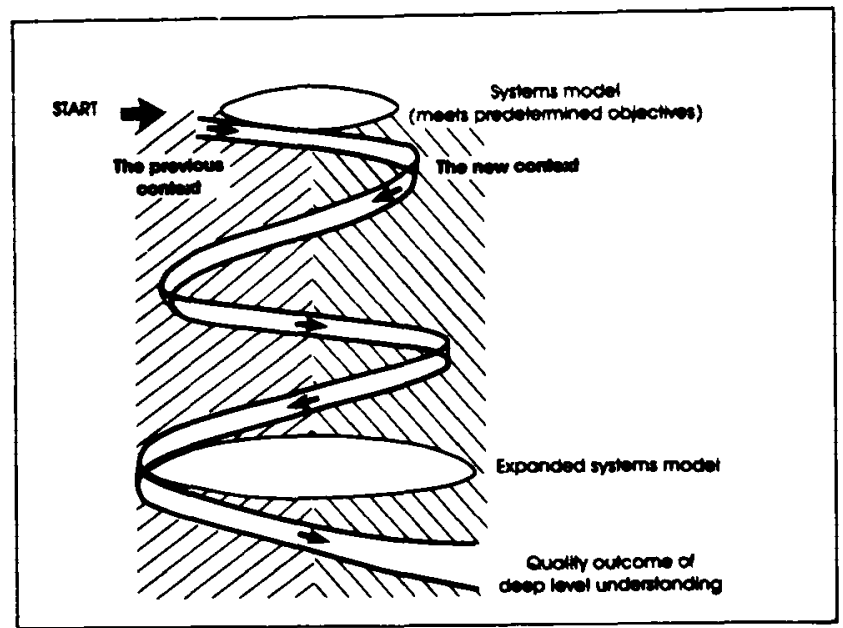

Fagure 3 Cognitive socialization for quality outcome.

new requirements. When he finds his contributions unacceptable, his self-esteem is lowered and a feeling of marginality develops (Human \& Hofmeyr, 1985:113, 125). His living conditions may either reinforce his previous frameworks or contribute to their destruction or restructuring. For example, visits home might tend to reinforce previous standards. On the other hand the support of a peer more experienced in the new context might hasten adaptation.

Educational interventions in the UCS were of two kinds. First, there were those that aimed to clarify the explicit context of, for example the university, by helping to identify and practise the skills required for successful study. Clarification of the implied context of the industrialized world included special English classes in which economic topics were discussed. Classes in Economic History aimed to provide an enriched understanding of the total context in which subjects such as Economics and Business Economics are studied. Each cadet was provided with an essay tutor by the sponsors, that is a young company executive with whom university assignments could be discussed. A vocational training programme included visits to other companies and places of interest such as the Stock Exchange, and a business game during which attention could be focused on specific events such as, for example, financing a business through debt capital. In applying a socialization model the systems model was not totally abandoned, but was expanded and modified for the appropriate level of understanding which the student reached as he progressed.

Mere exposure to the new context proved to be insufficient because stimulus was needed to encourage the student to apply his thought processes, that is his cognitive skills, in context so that he could relate his learning to a reality outside the immediate environment of the lecture or textbook. The type of cognitive activity that appears to be required in, for example, Economics and Business Economics is shown in Figure 4.

This represents what may happen when an assignment is set. The student who processes only at surface level takes the short cut to producing his assignment. For the learning outcome to be one of quality the student must take a longer route going through one or more thought processes, abstracting the meaning and relating it in its wider significance to an outside reality. For the second language student from a culture other than that of modern technological society, the outside reality may differ because of the influence of the previous context. For example, cadets appeared to have very

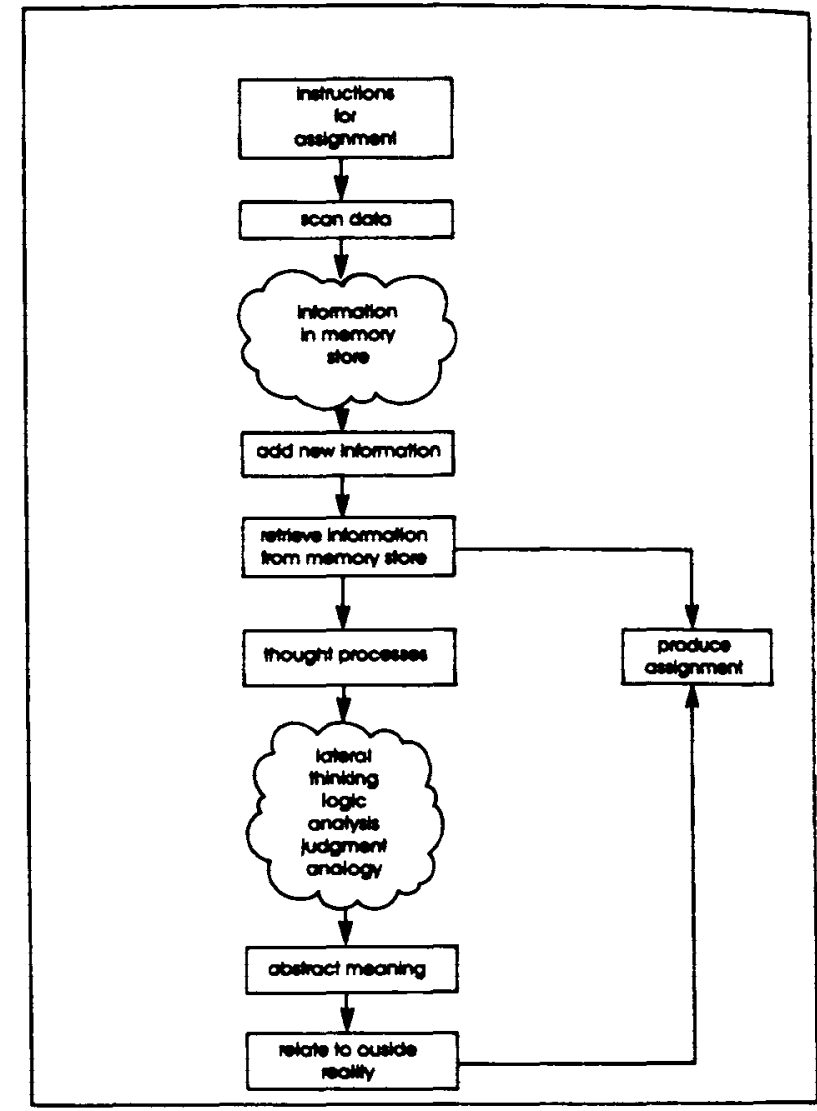

Figure 4 Surface and deep level processing: requirements in cognitive activity.

little sense of historical context as seen in strictly western terms, hence the inclusion of Economic History as an additional subject for study.

\section{Conclusion}

The systems approach had identified the skills necessary for competing equally in modern technological society. The process and research approaches to curriculum development provided an additional dimension of depth to what was being attempted. The model of cognitive socialization, in taking a more eclectic view, did not lose sight of the original objectives. They were, however, placed in the context of the situation in which they were to be applied. Thus, for example, under the systems approach, students were required to draw inferences from statements which were presented to them without reference to any particular context. The objective was that students should be able to think logically. When the model of cognitive socialization was applied, students were asked to draw inferences from statements made, for example, in an economics lecture. The inferences drawn were discussed with the group of cadets so that the cognitive skills (in this case logical thinking) were activated in the context of the situation for which they were required. It was hoped in this way to promote deep level understanding and that quality learning would ensue. Similarly, educational experiences in listening and note-taking, reading, writing, observation, and examination skills were all undertaken with a view not only to the acquisition of the skill per se, but to promote a deep understanding of the subject for which the skill was used. Gradually through the process of cognitive socialization the outside reality to which students related their thinking approximated more nearly that of English-speaking persons reared in modern technological society.

This paper has described the development and implementa- 
tion of a model of cognitive socialization for persons of a culture other than that of modern technological society entering the English-speaking business world of South Africa in the eighties. The reader may be left with the impression that the question of Africanization has been avoided and this is indeed the case. There has been no intention to present a view which ignores cultures which do not subscribe to the values of modern technological society. However, assuming that South African blacks want to participate in the modern world of technology, and bearing in mind the socio-economic political situation, then one way to Africanization, that is, one way to structures and policies planned and administered by blacks might be through black advancement, in other words through programmes such as described above. In such cases black advancement could be regarded as a stepping-stone to Africanization. Through black advancement programmes the needs of contemporary economies would be better understood. Then as numbers of blacks in decision-making positions increase over time, and as black confidence grows, structures and policies can be changed by those in control.

Another option would be a concerted effort on the part of both blacks and whites to take the best of each other's cultures in bringing about a new South African life-style (Holdstock, 1981; Kruger, 1983). The model of cognitive socialization would then have to be developed to include the socialization of whites into certain black ways of thought and behaviour. Educational programmes would have their twofold aims of enabling both blacks and whites to compete in modern technological society and to understand the values of each other's cultures.

As a post-script it is pleasing to note that the first group of cadets trained on a socialization model have recently graduated (1986). Hopefully they will continue in their careers to deepen their understanding and produce work of quality which they themselves have related to the context in which they now find themselves. Clearly many factors other than the model of cognitive socialization have had their influence, but they are outside the scope of the present article.

\section{Acknowledgements}

The financial assistance of the Human Sciences Research Council towards the costs of this research is gratefully acknowledged. Opinions expressed or conclusions reached are my own and are not to be regarded as a reflection of the opinions and conclusions of the Human Sciences Research Council. I am indebted to Dr L. Human for many helpful suggestions.

\section{Roferences}

Bransford, J.D. \& McCarrell, N.S. 1975. A sketch of a cognitive approach to comprehension: some thoughts about understanding what it means to comprehend. In: Thinking: Readings in Cognitive Science. Johnson-Laird, P.N. \& Wason, P.C. (Eds), 1977. Cambridge University Press, 377-399.

Brown, R.W. 1956. Language and Categories. In: $A$ Study of Thinking. Bruner, J.S., Goodnow, J. \& Austin, G.A. 1956. Appendix. N.Y.: John Wiley, 247-312.

Bruner, J.S. 1974. Beyond the information given. In: How students learn. Entwistle, N. \& Hounsell, D. (Eds). Lancaster Institute for Research and Development in Post Compulsory Education: University of Lancaster, $105-116$.

Cohen, L. \& Manion, L. 1980. Research methods in education. London: Croom Helm, 174-189.

Criper, C. \& Widdowson, H.G. 1975. Sociolinguistics and Language Teaching. In: The Edinburgh Course in Applied
Linguistics: Volume Two: Papers in Applied Linguistics. Allen, J.P.B. \& Corder, S.P. (Eds). London: Oxford University Press, $155-217$.

Dahlgren, L.O. \& Marton, F. 1978. Students' conceptions of subject matter: an aspect of learning and teaching in higher education. Studies in Higher Education, vol. 3,1.

Davies, I.K. 1971. The Management of Learning. N.Y.: McGraw Hill.

Education Press, 1983. Mphahlele, E., Mpakanyane, M. \& Mashabela, H.H. (Eds). Johannesburg: Sached, vol. 1, 3, 4-5.

Edwards, J.R. 1979. Language and Disadvantage. London: Arnold.

Fillmore, C.J. 1973. A grammarian looks to sociolinguistics. In: Sociolinguistic Aspects of Language Learning and Teaching. Pride, J.B. (Ed), 1979. Oxford: Oxford University Press, 2- 16.

Gibbs, G., Morgan, A. \& Taylor, E. 1982. A Review of the Research of Ference Marton and the Goteborg Group: A phenomenological research perspective on learning. Higher Education, vol. II, 123-145.

Holdstock, T.L. 1981. Psychology in South Africa belongs to the colonial era: Arrogance or ignorance? S. Afr. J. Psychol., vol. $11,4,123-129$.

Human, L. 1984. The black manager in a white world: a reformulation of the problem area (1) In: Proceedings of Second International Conference on Case Method Research and Application. Winterburn, N.R. (Ed). London: April.

Human, L. \& Hofmeyr, K. 1985. Black managers in South African organisations. Cape Town: Juta.

Kruger, D. 1983. The Africanisation of the white South African. Africa Insight, vol. 13, 2, 117-124.

Lanham, L.W. 1983. Social forces that determine the development of standards of spoken English in South Africa. Third talk of series: The English language as it is spoken in South Africa: SABC, University of the Air.

Manganyi, N.C. 1981. Looking through the keyhole. Johannesburg: Ravan Press.

Mayer, P. (Ed.) 1970. Socialization: the approach from social anthropology. London: Tavistock Publications.

Mead, Margaret. 1930. Growing up in New Guinea. N.Y.: Mentor Books.

Meyer, Margaret I. 1985. Study skills for a university education: unpublished doctoral thesis, Johannesburg: University of the Witwatersrand.

Mphahlele, E. 1981a. A proposal ... to ... the Council for Black Education and Research, October 31. Black Education Research: The Council for.

Mphahlele, E. 1981b. Towards a humanistic philosophy of education. Black Education Research: The Council for.

Pinto, D.D. 1985. Communication skills for a university education: unpublished doctoral thesis, Johannesburg: University of the Witwatersrand.

Piron, J., Human, L. \& Rajah, M. 1983. The men in the middle: supervisors in South African organisations today. S. Afr. J. Labour Rel., vol. 7, no. 3, September 1983.

Rowntree, D. 1974. Educational Technology in Curriculum Development. London: Harper Row.

Rowntree, D. 1982. Educational Technology in Curriculum Development. 2nd edition. London: Harper Row.

Schwartz, T. (Ed) 1976. Socialization as Cultural Communication. Berkeley: University of California Press.

Skemp, R.R. 1979. Intelligence, Learning and Action. Chichester: John Wiley.

Stenhouse, L. 1975. An Introduction to Curriculum Research and Development. London: Heinemann.

Vygotsky, L.S. 1962. Language and Thought: The Problem and the Approach. In: The Psychology of Language, Thought, and Instruction. De Cecco, J.P. (Ed) 1967. N.Y.: Holt Rinehart, $56-60$.

Welsh, D. \& Savage, M. 1977. The University in Divided Societies: The Case of South Africa. In: The Future of the University in Southern Africa. Van der Merwe, H.W. \& Welsh, D. (Eds) 1977. Cape Town: David Philip, 130-147. 